\title{
EDUCAÇÃO INTEGRAL: IDEAL ACALENTADO E CONCEITO MALTRATADO
}

\author{
Paulo Moacir Godoy Pozzebon* \\ Samuel Mendonça**
}

\begin{abstract}
Resumo: O ensaio objetiva discutir formas de apropriação conceitual do ideal de educação integral. A partir do método de revisão bibliográfica, contemplando referências históricas do pensamento pedagógico, a legislação educacional brasileira e a literatura educacional brasileira contemporânea, buscase apreender em que consiste a educação integral. Os resultados evidenciam que não há homogeneidade na compreensão da educação integral, embora, paradoxalmente, exista consenso em sua busca. Além da necessidade de maior aprofundamento conceitual e contextualização histórica, as elaborações em torno da educação integral são muito divergentes e não aprofundam o seu sentido, fornecendo balizas superficiais para políticas públicas e assimilando-a a políticas de proteção social. Por fim, o debate sobre o tema reivindica a fundamentação a partir de uma filosofia do ser humano que discuta, efetivamente, a integralidade de suas dimensões constitutivas e permita sua expressão em termos de necessidades educativas.
\end{abstract}

Palavras-chave: Educação Integral; Políticas Públicas; Educação; Filosofia.

Resumen: El ensayo pretende debatir formas de apropiación conceptual del ideal de educación integral. Basándose en el método de revisión bibliográfica, contemplando las referencias históricas del pensamiento pedagógico, la legislación educativa brasileña y la literatura educativa brasileña contemporánea, buscamos aprehender en lo que consiste la educación integral. Los resultados demuestran que no hay homogeneidad en la comprensión de la educación integral, aunque, paradójicamente, hay consenso en su búsqueda. Además de la necesidad de profundizar conceptual y contextualización histórica, las elaboraciones en torno a la educación integral son muy divergentes y no profundizan su significado, proporcionando balizas superficiales para las políticas públicas y asimilándolo a políticas de protección social. Por último, el debate sobre el tema reivindica el razonamiento basado en una filosofía del ser humano que discute efectivamente la integralidad de sus dimensiones constitutivas y permite su expresión en términos de necesidades educativas.

Palabras claves: Educación integral; Políticas Públicas; Educación; Filosofía.

\section{Introdução}

A sociedade brasileira compartilha, entre seus mais acalentados ideais, a ideia de educação integral. É consenso. Está na Constituição Federal brasileira (BRASIL, 2018a) e em diversas outras importantes leis relacionadas à educação (BRASIL, 2018b; 2018c). Todas as propostas educacionais a mencionam. Inúmeros colégios recrutam

\footnotetext{
* Doutorando em Educação pela PUC-Campinas. Email: paulopozzebon20@gmail.com.

** Professor Titular. Programa de Pós-Graduação em Educação da PUC Campinas.

E-mail: samuelms@gmail.com.
}

alunos com a promessa de formação integral, dado que as famílias a valorizam e a buscam para seus filhos. Educação integral é, por isso, uma referência permanente no universo educacional brasileiro.

Mas em que consiste a educação integral? As definições são múltiplas e aparecem com facilidade. Trata-se da educação multidimensional da criança e do jovem, envolvendo todas ou a maior parte das dimensões constitutivas do ser humano, como expresso em Gonçalves (2006, p. 129):

O conceito mais tradicional encontrado para a definição de educação

POZZEBON, Paulo Moacir Godoy; MENDONÇA, Samuel. Educação integral: ideal acalentado e conceito maltratado. Revista Sul-Americana de Filosofia e Educação. Número 32/33: nov. 2019 out. 2020, p. 174-200. DOI: https://doi.org/10.26512/resafe.v1i32/33.35121 
integral é aquele que considera o sujeito em sua condição multidimensional, não apenas na sua dimensão cognitiva, como também na compreensão de um sujeito que é sujeito corpóreo, tem afetos e está inserido num contexto de relações. Isso vale dizer a compreensão de um sujeito que deve ser considerado em sua dimensão bio-psicossocial. Acrescentamos, ainda, que o sujeito multidimensional é um sujeito desejante, o que significa considerar que, além da satisfação de suas necessidades básicas, ele tem demandas simbólicas, busca satisfação nas suas diversas formulações de realização, tanto nas atividades de criação quanto na obtenção de prazer nas mais variadas formas.

Educação integral é, portanto, um objetivo desejável e plenamente justificável, especialmente para educação de crianças $e$ jovens. Entretanto, quando nos aproximamos mais do tema, para examiná-lo e eventualmente discuti-lo, observamos que tem sido tratado com insuficiente profundidade. A própria literatura especializada da área faz uma discussão derivada (SAVIANI, 2007; COELHO, 2009): não aprofunda o conceito e suas condições ou fundamentos, mas focaliza sua utilização no regime da escola, associado a tempo integral e a composição curricular. O consenso em torno da educação integral se mostra apenas aparente. É nesse sentido que este ensaio objetiva discutir formas de apropriação do conceito de educação integral.

Cabe então perguntar: o que é educação integral, como evoluiu esse conceito $e$ que significado ele tem hoje, em diferentes correntes do pensamento pedagógico? $\mathrm{O}$ método utilizado diz respeito a revisão bibliográfica clássica, isto é, não sistemática, es- colhido devido à amplitude das fontes a serem consideradas.

\section{1 - Expressões do ideal de educação integral}

Referimo-nos à educação integral como ideal. Utilizamos esse termo em sentido próximo do uso kantiano, apropriado de Rousseau (DALBOSCO, 2011) isto é, a ideia de uma perfeição completa, mas não concretamente realizada, que serve como modelo $e$ como critério de avaliação das realidades objetivas (ABBAGNANO, 1982, p. 497). O motivo dessa escolha é que, dos gregos aos contemporâneos, a educação integral é proposta como algo a ser buscado ou construído, não como realidade plenamente disponível. Passamos, então, a analisar como esse ideal foi formulado distintamente em diferentes situações, ao longo do tempo.

O ideal de educação integral encontrou sua primeira expressão no ideal educativo grego. Este se exprimia, nos primeiros séculos, como areté (JAEGER, 2001, p. 25), isto é, a excelência ou nobreza (JAEGER, 2001, p. 26), conjunto de características físicas, espirituais e morais inatas que caracterizavam os heróis dos poemas homéricos.

Aos poucos, esse ideal se alargou, abrangendo não apenas características inatas, mas o produto do aprendizado, e passou a se exprimir como kalokagathia, isto é, a excelência física e espiritual do guerreiro belo e bom, "[...] educação total de espírito $e$ de corpo do nobre [...], baseada numa concepção total do Homem" (JAEGER, 2001, p. 336), ainda concebida como apanágio da aristocracia.

A partir do século $V$ a.C., período das guerras helênicas, do fortalecimento das cidades, do surgimento da democracia e do 
auge da cultura grega, o ideal educativo passou a exprimir-se como paideia, em outros termos, a formação ampla e consciente do espírito (JAEGER, 2001, p. 337) que pretendia constituir o homem como cidadão (JAEGER, 2001, p. 336). Essa formação abrangia todas as formas de criação cultural $e$ todo o patrimônio cultural grego, das primitivas concepções religiosas à racionalidade que aos poucos se impunha, estendida a todos os cidadãos livres, não apenas à nobreza. Exemplificam diferentes faces dessa nova educação as instituições educacionais de Esparta e Atenas, que elaboraram e procuraram, ao longo dos séculos, concretizar "[...] um ideal consciente de educação e de cultura" (JAEGER, 2001, p. 484), que deve ser entendido como "[...] um ideal novo $e$ superior de formação humana e de ligação do indivíduo à coletividade" (JAEGER, 2001, p. 486).

Na cidade-estado de Esparta, toda a vida social $e$ a maior parte da educação eram organizadas pelo Estado. Esta tinha como ideal pedagógico: "[...] formar cidadãos respeitosos com os deuses, patriotas, bravos e fortes, pelo Estado e para o Estado" (LARROYO, p. 140). Até sete anos a criança permanecia sob os cuidados da mãe. Dos sete aos 12 , o menino recebia educação pública, obrigatória, ministrada em estabelecimentos de tipo militar. Esta consistia em cultura física (ginástica, corrida, salto, luta, disco), dança, cultura musical (embora menos enfatizada que cultura física), leitura e escrita limitados e formação moral cuidadosa, voltada para o respeito aos velhos, obediência e honra. Dos 12 aos 18 anos, o adolescente recebia educação de caráter militar; dos 18 aos 20 , exercia funções de vigilância policial da cidade e dos escravos; dos 20 aos 30, residia em academias militares. Chama a atenção o fato de que, em Esparta, as mulheres também recebiam educação obrigatória, em que era dada ênfase à ginástica $e$ dança, mas também à disciplina, honra $e$ valentia (LARROYO, 1982).

Em Atenas consolidou-se o ideal da formação completa do homem. Nos primeiros séculos, isso significava o ideal do guerreiro belo e bom. Mais tarde tomou a forma do ideal de educação física associada à educação intelectual. Entretanto, "Tal era a antiga educação ateniense, mais artística que literária e mais esportiva que intelectual" (MARROU, 1975, p. 77).

Dos sete aos 13 anos, um pedagogo acompanhava a criança e a conduzia à escola. Compunham o ensino a ginástica (salto, corrida, disco, dardo e pugilato), a gramática (leitura, escrita e cálculo), religião, história, geografia e ciência natural, utilizando como fontes os poetas. Dos 13 aos 17 anos, davase o início da formação secundária, para jovens abastados: ginástica, matemáticas, música, poesia. Os jovens pobres são encaminhados ao aprendizado de ofício agrícola ou mecânico. Aos 18 anos dava-se a efebia, isto é, o serviço militar que conduzia à maioridade, em que o jovem recebia, além das artes militares (esportes, lutas, manejo das armas, navegação, equitação), instrução cívica, moral e religiosa (LARROYO, 1982).

Foi no contexto da multiplicidade e diversidade das cidades-estados gregas e de suas tradições educativas que surgiu a reflexão pedagógica fundamentada no saber racional, isto é, o pensamento de um novo tipo de sábios, os filósofos. 
Cabe mencionar, por sua importância, os Sofistas, professores que iam de cidade em cidade para instruir os jovens abastados das classes comerciantes. Seu ensino, que pode ser entendido como de nível superior, abrangia a dialética, a retórica, a gramática, a política, a matemática, as ciências naturais e as artes. O objetivo era formar políticos, ou seja, cidadãos capazes de discursar nas assembleias com eloquência $e$ êxito e nelas representar as classes de que se originavam. Os Sofistas eram, sobretudo, pedagogos: "[...] a cavaleiro de uma cultura amadurecida, educadores proficientes elaboraram uma nova técnica, um ensino mais completo, mais ambicioso e mais eficiente do que aquele que os precedera" (MARROU, 1975, p.84). Proporcionando ensinamentos mais aprofundados que os dos mestres gramáticos de então e ensinando disciplinas que até então eram cultivadas apenas em círculos fechados, os sofistas promovem um ensino de nível superior, que a tradição posterior conservará, com variantes, no trivium e no quadrivium medievais e nas "sete artes liberais" (JAEGER, 2001, p. 368; LARROYO, 1982, p. 159; MARROU, 1975, p. 95).

Consideram-se, como principais sofistas, Protágoras (480-410), conhecido pelo relativismo filosófico; Górgias (483-375) cujo pensamento filosófico caracterizava-se pelo niilismo; e também Pródico, Hípias, Antifronte, Lícofron, Pólo, Trasímaco e Cálicles.

Contemporâneo dos Sofistas, tem destaque na história do pensamento filosófico o ateniense Sócrates (469-399 a.C.). Esse pensador não deixou textos escritos e suas ideias são conhecidas por meio das obras de seus discípulos (Platão e outros), do historia- dor Xenofonte e do poeta satírico Aristófanes (JAEGER, 2001, p. 499; MARROU, 1978, p. 98).

Seu pensamento caracterizava-se pela confiança na razão e oposição ao relativismo e niilismo dos sofistas. Creditam-se a Sócrates as doutrinas do conceito, entendido como conhecimentos universalmente válidos, $e$ das virtudes éticas. No domínio ético, professava o intelectualismo moral: o conhecimento das coisas e das virtudes leva o homem a agir corretamente e praticar o bem.

Seu método para filosofar era também seu método pedagógico: a Maiêutica (parto das ideias), que visa a levar o indivíduo a descobrir a verdade. Procede por meio de autêntico diálogo, em que um tema é introduzido na conversação e em seguida, por meio de interrogações e repostas, o interlocutor é levado a perceber que seus conhecimentos são superficiais e contraditórios. Prossegue, então, sempre por meio de interrogações e respostas, em busca do conhecimento verdadeiro sobre o tema. Ressalte-se que esse método, além de marcar profundamente a história do pensamento filosófico, permanece como método pedagógico até os dias atuais, especialmente na educação liberal (liberal arts) de algumas universidades europeias e norte-americanas (HABERBERGER, 2018; HISTORY, 2017).

Amado (2007) registra a influência dos Sofistas e de Sócrates, bem como de seus sucessores, como uma verdadeira revolução operada na educação ateniense, que transformou o ideal educativo tradicional, conferindo-lhe um viés intelectualista que nunca mais perderia:

Graças ao testemunho precioso de Aristófanes acerca dessa revolução, podemos perceber como ela tocou 
no âmago da forma ateniense de encarar a Paideia. Esta revolução foi tão profunda que, a bem dizer, até aos nossos dias ainda não nos desviámos significativamente da opção intelectualista e verbalista então tomada. As nuances da oposição colorida entre Sócrates e os Sofistas como, logo mais, entre Platão e Isócrates, não escondem que aquilo a que assistimos aqui é ao enterro do ideal

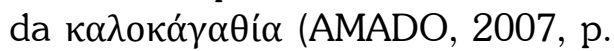
28).

Também na área da educação, Platão (429-347 a.C.) é referência obrigatória. Discípulo de Sócrates e fundador da Academia, de seus numerosos escritos destacam-se, pela dimensão pedagógica clara, "A República" (PLATÃO, 2000), "As Leis" (PLATO, 2003) e o "Banquete" (PLATÃO, 1983).

Platão compartilhava o problema central dos filósofos gregos: como explicar o movimento e o ser? Sintetizando as contribuições de Heráclito e de Parmênides, afirmava que o mundo sensível só se explica por meio do suprassensível; o relativo, por meio do absoluto; o mutável, por meio do imutável; o corruptível, por meio do eterno (MORENTE, 1967; REALE, ANTISERI, 1990). Por isso, o 'verdadeiro' ser é constituído pela realidade inteligível. O mundo inteligível, que não é um lugar físico em separado, contém as Ideias de todas as coisas. Essas não são simples conceitos, abstratos, mas substâncias, verdadeiro ser, ser por excelência, paradigmas, essências das coisas. São também perfeitas e incorruptíveis, sem cor, sem figura e intangíveis e só podem ser contempladas pelo intelecto. Quem as contempla possui conhecimento da realidade (ciência) e a compreende verdadeiramente. Quem não contempla as ideias não possui conhecimento, mas toma aparências por realidade, no nível que Platão denomina "doxa" ou "opinião". No campo político, amplamente desenvolvido na "República", Platão (2000) defendeu o governo dos sábios, isto é, exercido por aqueles que contemplam as Ideias e possuem conhecimento das realidades ligadas ao governo.

No homem, o corpo, que é parte do mundo sensível, opõe-se à alma, que é parte do mundo suprassensível. O corpo é tumba e cárcere da alma, onde esta expia penas de uma vida anterior. Tributário da natureza da matéria, o corpo é a causa de males, ignorância, paixões, loucura e mesmo da morte do homem. Por sua vez, a alma se eleva do sensível ao Inteligível pelo conhecimento e se purifica. Com a purificação e a morte, busca voltar ao mundo inteligível. Daí deriva a concepção de que a razão e a filosofia possuem força salvífica (PLATÃO, 1983).

As ideias pedagógicas de Platão estão expostas na República, nas Leis e mais alguns diálogos. Inspirado na educação espartana, Platão, na análise de Larroyo (1982), afirmava que a educação deve ser pública, controlada pelo Estado e estruturada de acordo com as aptidões dos alunos. Dos três aos seis anos, a criança deve receber treinamento físico, estético e moral na família. Dos sete aos 13 anos, todas as crianças devem frequentar a escola, que lhes proporcionará uma introdução gradual na cultura intelectual e reforço do cultivo do corpo. Dos 13 aos 16 anos, a escola deve ensinar gramática, aritmética, poesia, canto coral, dança e citara. Dos 17 aos 20 anos, o jovem deve receber formação militar, música e ginástica. A educação superior, dos 21 anos em diante, destina-se somente aos melhores, que seriam 
formados para integrar a classe dos governantes. Estes receberiam, dos 21 aos 30 anos, conhecimentos aprofundados de aritmética, geometria, astronomia e harmonia musical; dos 31 aos 35 anos, formação filosófica e dialética, além de matemática. Aos 36 anos, poderiam assumir funções públicas (LARROYO, 1982).

A proposta platônica não representa mera repetição da tradição espartana. Cada um dos saberes a ser transmitido às crianças e aos jovens tem papel específico na formação de suas almas. Cumpre destacar ainda, no pensamento platônico, a relação entre faculdades individuais e funções sociais. Almas em que aprouve aos deuses misturar bronze têm sensibilidade grosseira, marcada por apetites e desejos. Sua virtude é a temperança e devem ser destinados à classe industrial, cuja função é ocupar-se de comércio e ofícios. Almas a que os deuses deram prata destacam-se pela força de suas paixões. Sua virtude é a fortaleza e sua função social é militar, encarregada da guerra. As almas a que os deuses misturaram ouro destacam-se pela faculdade intelectual. Sua virtude própria é a prudência e sua classe social é a dos sábios, encarregados da busca do conhecimento e da sabedoria (PLATÃO, 2000).

Antropologia, epistemologia, ontologia, ética, política e educação se imbricam estreitamente no pensamento de Platão e não devem ser pensadas separadamente. A proposta educativa não apenas instrui, mas, apoiada na constituição humana e na estrutura do real, pretende levar à perfeição a cidade e seus cidadãos. Nesse sentido, o pensamento platônico representa continui- dade do ideal de educação integral, bem como uma de suas expressões clássicas.

No esteio da tradição pedagógica iniciada pelos filósofos, mas certamente aprofundando-a, cabe mencionar Aristóteles (384-322). Nascido em Estagira, foi discípulo de Platão na Academia. Mais tarde, tendo desenvolvido um vigoroso pensamento autônomo, fundou o Perípato (ou Liceu) em 335 , onde reuniu discípulos para lições esotéricas, reservadas e destinadas aos mais adiantados, e lições exotéricas, voltadas para os mais jovens e ao público em geral (REALE, 2012). Alguns de seus textos pedagógicos mais importantes estão inseridos na Política, livros VII e VIII (ARISTÓTELES, 2018).

Também em Aristóteles imbricam-se ontologia, epistemologia, antropologia, ética, política e educação. Seu projeto é a cidade feliz, organização política em que se realiza o bem comum. Na ontologia aristotélica, todas as coisas são substâncias (unidade que suporta as características da coisa) nas quais se podem distinguir: essência (predicados da substância que fazem dela o que ela é) e acidentes (predicados contingentes); matéria (aquilo de que é feito algo: madeira, palavras etc) e forma (conceito que representa a figura, ou formato, e sobretudo o princípio organizador e unificador de algo, sua essência; e ainda o fim que dá sentido à coisa); ato (o que veio a ser, o concretizado) e potência (o que virá a ser, virtualidade ligada à matéria). Todas as coisas são uma mistura de potência e ato. $\mathrm{O}$ movimento do real, ou mudança, é explicado pela passagem da potência ao ato. O real é inteligível $e$ a inteligência é a faculdade da alma que permite conhecê-lo. Conhecer é formar conceitos e com eles constituir juízos e raciocínios. Pen- 
sar é ato humano por excelência; a racionalidade é a qualidade distintiva da natureza do homem (MORENTE, 1967).

Iniciador da Psicologia na Antiguidade, Aristóteles, na análise de Larroyo (1982), identifica uma base psicológica para a educação, que pode ser resumida nas teses seguintes: a criança se educa à medida em que imita o comportamento dos adultos e a imitação se torna um hábito; a educação se dá pelo desenvolvimento das disposições naturais do educando (passagem da potência ao ato); são fatores da educação as disposições naturais, os meios para aprender, a prática $e$ o hábito do aprendido; o processo psíquico do conhecimento compreende a percepção do objeto, memorização do percebido e aplicação dos conteúdos memorizados. Daí o método de ensinar: o mestre expõe a matéria, cuida para que o aluno a retenha e busca que o aluno exercite e relacione os conteúdos (LARROYO, 1982).

Aristóteles propõe à cidade uma educação gradual, voltada para o desenvolvimento das potencialidades humanas, de acordo com as características de cada idade, buscando aperfeiçoá-las. Deve também ser integral, abrangendo as dimensões intelectual, moral e física. Deve ser pública e comum, de responsabilidade do Estado, ministrada a todas as classes sociais, com exceção de escravos e artesãos (LARROYO, 1982). Iniciase pelo desenvolvimento do corpo, depois prossegue com a educação dos impulsos, dos instintos e dos apetites e completa-se com a educação da alma racional (REALE, 2012, p. 139). Assim, até os seis anos, a criança deve ser educada pelos pais, que, entretanto, continuam corresponsáveis pela educação moral, após esse período. Dos sete anos até a puberdade, deve ficar sob o controle do Estado, estudando leitura, escrita, música, desenho, cultura física e gramática. Da puberdade até os 21 anos o jovem deve receber formação militar, além de formação intelectual, que compreende música, retórica, matemática, filosofia e política (LARROYO, 1982).

$\mathrm{O}$ auge da paideia deu-se no Helenismo, isto é, durante e após o império de Alexandre, quando se difundiu na orla mediterrânea o ideal educativo helenístico. Neste, a cultura física perde importância diante dos elementos intelectuais e toma forma uma cultura considerada clássica e humanista, essencialmente estética, artística e sobretudo literária, onde está presente também a filosofia.

A paideia assumiu, assim, novo $e$ ampliado significado, no qual está claro seu caráter de educação integral:

[...] por uma ampliação notável [...] a mesma palavra, em grego helenístico, serve para designar o resultado desse esforço educativo, continuado para além dos anos escolares durante toda a vida, a fim de realizar mais perfeitamente o ideal humano: $\pi \alpha \iota \delta \varepsilon i ́ \alpha$ (ou $\pi \alpha i ́ \delta \varepsilon v \sigma \iota \varsigma$ ) vem a significar a cultura, entendida não no sentido ativo, preparatório, de educação, mas no sentido perfectivo que a palavra tem hoje entre nós: o estado de um espírito plenamente desenvolvido, tendo desabrochado todas as suas virtualidades, o do homem tornado verdadeiramente homem; [...] (MARROU, 1975, p. 158).

O significado e a importância da paideia helenística são registrados por Marrou:

A educação helenística é realmente o que devemos chamar a educação clássica: é a de todos o mundo grego, quando se estabiliza após as grandes aventuras da conquis- 
ta de Alexandre e das guerras que sucederam a sua morte. Ela permanece em voga, em todo o mundo mediterrâneo, por tanto tempo quanto este merece ser considerado antigo [...] sua importância na história do período helenístico é tão grande que devemos considera-la como o verdadeiro centro de todo quadro sincero dessa civilização (MARROU, 1975, p. 154 e 156).

O Império Romano absorveu a influência da paideia helenística, associando a ela seu ideal de homem de bem, concretizado na figura do orador hábil e virtuoso. Os escritos de Cícero, Varrão e Quintiliano deram voz a esse novo ideal, ao mesmo tempo ético, político e pedagógico, que aos poucos passou a ser designado pelo nome de "humanismo". A formação do orador, de acordo com Cícero, compreendia vasta cultura geral, abrangendo gramáticas, retórica, dialética, geometria, astronomia, música e aritmética, ao que se deveria completar com história, direito $e$ filosofia. (SIMARD, 2000, p. 40).

$\mathrm{O}$ encontro entre a filosofia grega, greco-romana e o pensamento teológico cristão produziu gradativamente uma síntese intelectual, conciliando razão e fé religiosa, elaborada nos primeiros séculos da era cristã pelos chamados "padres da Igreja". Dela resultou um conjunto importantíssimo de obras, que alguns autores denominaram "paideia cristã". Representa seu ápice a vasta obra de Agostinho de Hipona. Este, em seu diálogo "De Magistro" Agostinho (1980), desenvolveu uma teoria do conhecimento $e$ da linguagem, ao mesmo tempo em que propôs uma pedagogia em que professores $e$ conteúdos cumprem o papel preliminar de convidar o indivíduo a empenhar-se na busca do conhecimento e apreender a verdade com o mestre interior, que é Deus. Sintetizando a fé cristã e a influência de Cícero, Agostinho argumentava, na interpretação de Simard (2000), que o homem educado deve ser letrado e capaz de eloquência, mas deve ser também um erudito, isto é, possuidor da cultura geral literária que a tradição clássica colocava na base da formação do orador. (SIMARD, 2000, p. 40).

Da paideia grega à Patrística, passando pelos filósofos gregos do IV século a.C., pelo helenismo e pelos pensadores romanos, estende-se o percurso do ideal de educação integral, ora aprofundando-se, como em Platão e Aristóteles, ora adaptando-se a novos contextos sociais e culturais, como em Roma e na obra de Agostinho.

Na Idade Média, as tradições pedagógicas vindas da antiguidade greco-romana e do Cristianismo tomaram um corpo definido e estável na instituição pedagógica do trivium e do quadrivium. O trivium compunha-se de gramática, retórica e dialética; o quadrivium compreendia aritmética, geometria, música e astronomia. Baseados na lógica aristotélica, também na análise de Simard (2000, p. 35), essas disciplinas "[...] formam hábitos intelectuais de análise e de síntese, indispensáveis não somente para o exercício de uma vida livre e sensata, mas igualmente para ordenar os conhecimentos numa cultura geral sobre a qual virá eventualmente se enraizar uma formação especializada" (SIMARD, 2000, p. 35). Tais disciplinas passaram a ser denominadas "artes liberais", porque praticadas por homens livres e por serem essencialmente intelectuais, delas excluídas as artes servis, praticadas por servos. Iniciadas pelos Sofistas, consolidadas pelo Helenismo e sistematizadas pelas escolas 
medievais, as artes liberais representaram uma forma de persistência do ideal de educação liberal que, apesar da ênfase intelectualista e das fortes críticas que receberam, se estendeu até o século XVIII.

O Renascimento conservará sem muitas modificações o trivium e o quadrivium, contudo, privilegiando claramente o trivium e o submetendo ao conceito de obra clássica, que é criação própria do Renascimento. Ao conjunto constituído por gramática, retórica e comentário dos autores se deu o nome de "studia humanitatis" e de "litterae humaniores". "O humanismo se desenvolve então em uma forma educativa que se exprime num curriculum rigoroso e em obras ditas clássicas" (SIMARD, 2000, p. 35).

A Reforma trouxe a lume o esforço educativo de Lutero. Crítico agudo da Escolástica e da ignorância que, em sua perspectiva, dela derivava, exprimia uma visão bastante influenciada pelo ideal renascentista de educação, ao qual uniu suas concepções religiosas:

Se eu tivesse filhos para os educar, queria que aprendessem, além das línguas e da história, a música e as matemáticas. Não posso recordar-me sem dor que tive que ler, não os poetas e as histórias da Antiguidade, mas os livros dos sofistas bárbaros, com grande perda de tempo, com prejuízo para a minha alma, de tal maneira que ainda hoje me é difícil purgá-la dessas nódoas e dessa escória (LUTERO, apud., AMADO, p. 116).

No contexto da Contra-Reforma, os jesuítas elaboraram meticuloso trabalho de codificação das práticas pedagógicas extraídas da experiência dos professores e de definição de um conjunto de obras clássicas organizadas em etapas rigorosamente encadeadas e justificadas, com vistas a formar homens educados no humanismo e capazes de engajamento espiritual e moral a serviço da sociedade. (SIMARD, 2000, p. 35-36). Essa codificação está expressa no Ratio atque Institutio Studiorum, emanada em 1599. Obrigatório em todas as escolas jesuítas, imposto pela Coroa portuguesa a todos os seus domínios, esse ideal de cultura se difundiu e firmou amplamente na Europa e no Novo Mundo. A preservação do ideal da educação integral foi constatada por Leonel Franca (1952, p. 35): "Destarte, o Ratio Studiorum, num plano bem estruturado e harmonioso, faz convergir toda a vida escolar do colégio administração, currículo, metodologia, distrações - para um fim único: a educação integral do aluno".

A influência do racionalismo cartesiano, que concebe o ser humano essencialmente como razão, aliada ao advento da ciência moderna, deslocou a ênfase da educação para disciplinas científicas. As artes liberais, consagradas pelos séculos, adaptaram-se para acolher a influência científica sem, entretanto, ser abandonadas ou recusadas. Contudo, a ênfase parece ter-se deslocado do ideal de educação integral para o ideal de uma educação enciclopédica, isto é, ampla, mas inteiramente intelectual. É o que se pode ver, por exemplo, em Comenius (2001, p. 150-151):

1. Fixamos as metas a esta escola, de modo que, com quatro línguas, se abranja toda a enciclopédia das Artes, ou seja, de modo que, conduzindo devidamente os adolescentes por estas classes, consigamos:

I. Gramáticos competentes para fornecer, de modo perfeito, as razões de todas as coisas, em latim e na lín- 
gua nacional $e$, se necessário, em grego e em hebreu.

II. Dialéticos peritos em definir, distinguir, argumentar e em rebater os argumentos dos outros.

III. Retóricos ou Oradores capazes de discorrer elegantemente sobre qualquer tema.

IV. Matemáticos e

V. Geômetras, tanto para as várias necessidades da vida, como porque estas ciências preparam e aguçam o engenho para as outras.

VI. Músicos, práticos e teóricos.

VII. Astrônomos, versados, ao menos, nas coisas fundamentais, ou seja, na doutrina da esfera e no cômputo, pois, sem estas, a Física, a Geografia e a maior parte da História são cegas.

2. Estas são as tão decantadas sete Artes liberais, que o vulgo julga deverem ser ensinadas pelo professor de Filosofia. Mas, para que os alunos subam mais alto, queremos que haja também:

VIII. Naturalistas (Physici) que conheçam a composição do mundo, a natureza dos elementos, as diferenças dos animais, as propriedades das plantas e dos minerais, a estrutura do corpo humano, etc., considerando estas coisas, tanto em geral, como são em si mesmas, e ainda como coisas criadas para utilidade da nossa vida, o que compreende a parte que diz respeito à medicina, à agricultura e a todas as outras artes mecânicas.

IX. Geógrafos que tenham gravado na mente o globo terrestre, os mares, as suas ilhas, os rios, os Estados, etc.

$\mathrm{X}$. Cronologistas que saibam de cor a sucessão das várias épocas, desde o começo do mundo, e as suas divisões.

XI. Historiadores que saibam enumerar a maior parte das mais notáveis transformações do gênero humano, dos principais Estados e da
Igreja, e bem assim os vários costumes e ritos dos povos e dos homens. XII. Moralistas que conheçam exatamente os gêneros $e$ as diferenças das virtudes e dos vícios, e saibam fazer observar aquelas e levar a fugir destes, considerando tanto a sua idéia geral como a sua aplicação prática, relativamente à vida econômica, política, eclesiástica, etc.

XIII. Finalmente, queremos fazer Teólogos que, não só conheçam os fundamentos da sua fé, mas possam eles próprios ir hauri-los nas Sagradas Escrituras.

3. Desejamos que, terminado este curso de seis anos, os adolescentes sejam, em todas estas coisas, se não perfeitos (como efeito, nem a idade juvenil pode atingir a perfeição, nem é possível, em seis anos de instrução, esgotar o oceano), pelo menos possuidores de sólidos fundamentos, onde poderá assentar uma cultura mais perfeita.

O Iluminismo parece seguir na mesma direção, com exceção de Rousseau (1995). Em seu Emílio, esse filósofo desenvolve a ideia de um itinerário pedagógico em que a razão modela aos poucos as paixões desordenadas, conduzindo o educando ao exercício esclarecido de sua liberdade, condição essencial para sua participação, como cidadão, no Contrato Social (REALE; ANTISERI, 1990b, p. 772). Justamente por sua ênfase na preparação para a vida social, que é também moral e política, pode-se afirmar que Rousseau retomou a perspectiva da educação integral sem, entretanto, endossar o ensino das artes liberais.

Nos séculos XVIII e XIX, abriu-se nova $e$ importantíssima etapa no desenvolvimento histórico do ideal de educação integral, com a elaboração, na cultura alemã, da 
ideia de Bildung, que pode ser compreendida como formação cultural (SUAREZ, 2005). Com ampla ressonância de significados $e$ diferentes dimensões, a ideia de Bildung está presente na obra de intelectuais como Goethe e Humboldt e de um vasto rol de filósofos como Fichte, Schelling e Hegel. No campo da educação situa-se seu mais importante conjunto de significados.

[...] Os filósofos que fundamentaram o sentido desse conceito, com forte inspiração nos gregos, pensavam ser necessário o cultivo e o cuidado total para com a alma, de modo que os seres humanos pudessem alcançar metas mais elevadas. O constante contato com a filosofia, a arte e a literatura grega era considerado o mais essencial para possibilitar a formação. A peculiaridade da Bildung era o modo como ela prezava a formação espiritual, tendo como pressuposto o desprezo por todo $e$ qualquer caráter utilitário da educação: deve se ocupar da própria formação para se tornar um ser humano melhor, quer dizer, não há nenhum outro objetivo além da própria formação, ou seja, não tendo prevalência qualquer interesse profissional, social ou financeiro. O que faz com que, originariamente, a Bildung fosse uma particularidade da nobreza, pois os membros da aristocracia eram os únicos que poderiam passar por tal processo formativo. Com o ambicioso projeto da instauração de instituições de ensino, como o ginásio (equivalente a uma escola secundária, mas de conteúdo humanista $e$ clássico) e a moderna universidade, o conceito de Bildung sofreu algumas mudanças para poder se tornar democrático - mas com o mesmo significado fundamental de um cultivo da totalidade da personalidade. A formação do todo da personalidade relacionava-se principalmente ao de- senvolvimento de habilidades espirituais e morais do ser humano. De forma contrária ao homem moderno - o qual é cindido para se aplicar em específicos e únicos campos da vida -, os gregos eram formados como um todo, como uma unidade harmônica (e não de forma fragmentária), com o cultivo de seus mais variados dons e talentos de forma conjunta. Assim, o ideal da Bildung era o cultivo da totalidade da humanidade do homem, de modo que cada um pudesse se ocupar com muito mais do que uma mera área de estudo e pudesse aprender a lidar bem com seus sentimentos, instintos, pensamentos, paixões, desejos e sonhos (BAPTISTA, 2009).

Bildung representa assim uma das formas mais importantes do ideal de educação integral, pois ultrapassa a formação escolar, o saber enciclopédico associado às artes liberais e assume uma dimensão subjetiva e voluntária, com componentes existenciais. Paradoxalmente, sua influência, consubstanciada na fundação da Universidade de Berlim, parece ter provocado ou acelerado o declínio da educação liberal, abandonado nas universidades europeias que se voltaram para a pesquisa científica autônoma (PETERSON, 2011).

Importa mencionar que, por influência das universidades inglesas de Oxford $e$ de Cambridge, a educação superior baseada nas artes liberais foi transplantada para a América do Norte. O movimento inicia-se em 1636, com a fundação da Universidade de Harvard e é seguido por diversas instituições, em geral pequenas, de afiliação religiosa, que seguem os modelos de liberal arts de Oxford e de Cambridge. O método pode ser considerado socrático: discussão em grupos 
pequenos, com intenso feedback e grande abertura ao processo criativo. (HISTORY, 2017).

A reforma da universidade na Alemanha, em inícios do século XIX, da qual resultaram as universidades de pesquisa, ensejou também, na América do Norte, críticas agudas ao modelo educativo baseado nas artes liberais, postulando a necessidade de disciplinas científicas e, mesmo, de uma educação utilitária. A fortíssima influência positivista na Europa e nas Américas, na segunda metade do século XIX, deu força a essas críticas e o modelo de universidade baseada na educação liberal entrou em decadência em toda parte (HISTORY, 2017).

Entretanto, o modelo de educação liberal não desapareceu. Subsiste atualmente em numerosas faculdades e escolas secundárias norte-americanas. A American College Association caracteriza o objetivo da educação liberal como "[...] munir os estudantes de vasto conhecimento da cultura, da ciência e da sociedade (educação geral), bem como de um estudo aprofundado numa área específica de interesse" (PETERSON, 2011, p. 43). Além de amplos conhecimentos, a educação liberal visa à formação ética e social, direcionada à prática:

[...] ferramenta para ajudar os estudantes a desenvolver senso de responsabilidade social, bem como habilidades intelectuais e práticas sólidas e transferíveis. Tais habilidades incluem a de comunicação, de análise e de resolução de problemas, além de comprovada competência para aplicar conhecimentos e habilidades a um cenário real (PETERSON, 2011, p. 43).
Num discurso famoso de 1959, Leo Strauss procura identificar o diferencial formativo da educação liberal e justificar sua necessidade, tanto intelectual quanto politicamente:

A educação liberal é o antídoto para a cultura de massa, para os efeitos corrosivos da cultura de massa, para sua tendência inerente de produzir nada, a não se 'especialistas sem espírito ou visão $e$ apreciadores do prazer sem coração'. A educação liberal é a escada pela qual tentamos subir da democracia das massas a democracia em seu sentido original. A educação liberal é o esforço necessário para fundar uma aristocracia dentro da sociedade de democracia de massa. A educação liberal lembra aos membros de uma democracia de massa que tenham ouvidos para ouvir sobre a grandiosidade humana (STRAUSS, 2018).

Devido ao amplo espectro de conhecimentos mobilizados e aos objetivos éticos, sociais, políticos, comunicacionais e práticos, apesar do forte viés intelectual, a educação liberal contemporânea se reconecta à perspectiva da educação integral.

Parece pertinente uma palavra sobre o positivismo. Embora Comte (1978) advogasse a unificação das ciências, a formação de uma reforma das mentalidades no Ocidente e tenha chegado a prescrever a constituição e estudo de uma biblioteca positivista com 150 volumes, sua visão de educação segue o viés enciclopédico do Iluminismo, depositando apenas nos conhecimentos científicos a potencialidade transformadora da educação:

Tal maneira de proceder [a separação das disciplinas científicas] seria, pois, totalmente quimérica quanto à educação geral. No entanto, esta 
exige absolutamente um conjunto de concepções positivas sobre todas as grandes classes de fenômenos naturais. E tal conjunto que deve converter-se, de agora em diante, em escala mais ou menos extensa, até mesmo entre as massas populares, na base permanente de todas as combinações humanas, base que, numa palavra, deve constituir o espírito geral de nossos descendentes. Para que a filosofia natural possa terminar a regeneração, já tão preparada, de nosso sistema intelectual, é, pois, indispensável que as diferentes ciências de que se compõe, presentes para todas as inteligências como diversos ramos dum tronco único, se reduzam de início ao que constitui seu espírito, isto é, seus métodos principais e seus mais importantes resultados. Somente assim o ensino das ciências pode constituir para nós a base duma nova educação geral verdadeiramente racional. Que a essa instrução fundamental se acrescentem em seguida os diversos estudos científicos especiais, que devem suceder à educação geral, isto não pode evidentemente ser posto em dúvida (COMTE, 1978, p. 15).

Em função desse caráter restritivo do conhecimento a ser ensinado, entendemos que a reforma educacional propugnada por Comte (1978), que influenciou numerosos seguidores em diferentes países, afasta-se da ideia de educação integral.

Outra vertente da educação integral surge, no século XIX, com os movimentos genericamente denominados socialistas. No amplo leque de forças políticas e de intelectuais compreendidas pelo socialismo, destacam-se inicialmente os anarquistas Proudhon e Bakhunin que, de um modo geral, propõem uma formação que abrange as dimensões intelectual, física e moral da criança, visando sua formação para o trabalho, sua emancipação e realização como ser humano. Paul Robin, Sébastien Faure e Francisco Ferrer y Guardia dão desenvolvimento a essas ideias, que foram concretizadas em diversas experiências pedagógicas (SILVA, SOUZA, CUNHA, 2016, p. 129; PESTANA, 2014, p. 30). Mais tarde, aproveitando as reflexões dos socialistas utópicos e dos anarquistas, a tradição marxista preconizará, sob a denominação de "educação politécnica”, uma formação intelectual, moral, profissional e política, voltada para a superação da divisão do trabalho (intelectual e manual), para a transformação social e a emancipação do ser humano (MACIEL; MARTINS; BRASILEIRO, 2017). Gallo (1993, p. 35, apud., BEMVINDO, 2016, p. 143) esclarece como essas propostas pedagógicas podem ser consideradas formas de educação integral:

O cerne de toda a teoria pedagógica libertária é a ideia de educação integral. Essa discussão aparece muito cedo, e permeia todo o debate pedagógico entre os anarquistas, assumindo diferentes feições e interesses segundo os diferentes momentos históricos. A questão da educação politécnica (a rigor, o ensino de múltiplas técnicas) aparece nesse quadro da educação integral que consistiria, grosso modo, em educar o homem levando em consideração suas múltiplas facetas, que poderiam agruparse em três grandes dimensões: a físico, a intelectual e a moral.

Nos inícios do século XX, ganha força o movimento da Escola Nova, também denominado Escola Ativa e Escola Progressiva. Iniciado pelo suíço Adolphe Ferrière, notabi- 
liza-se nas décadas seguintes com os desenvolvimentos e sistematizações elaborados por Claparède, Montessori, Decroly, Dewey e Freinet. De um modo geral, essa nova pedagogia caracterizava-se pela valorização da atividade e da experiência, como fontes da motivação e do aprendizado. A educação deveria ser entendida não como preparação para a vida, mas como vida real, vivida em pequenas comunidades escolares, onde alunos e professores gozavam de autonomia para estudar temas e questões de interesse dos estudantes e vivenciavam relações de colaboração. Opunha-se, portanto, ao formalismo e conservadorismo da pedagogia tradicional, centrada "[...] na tradição, na cultura intelectual e abstrata, na autoridade, na obediência, no esforço e na concorrência" (CAVALIERE, 2002, p. 252).

Cavaliere (2002, p. 251) exprime as relações entre essa nova pedagogia e a educação integral:

Uma série de experiências educacionais escolanovistas desenvolvidas em várias partes do mundo, durante todo o século $\mathrm{XX}$, tinham algumas das características básicas que poderiam ser consideradas constituidoras de uma concepção de escola de educação integral. As próprias denominações assumidas por estas escolas já indicam muito de seus objetivos. Entre elas, podemos citas as "escolas de vida completa" inglesas; os "lares de educação no campo" $e$ as "comunidades escolares livres" na Alemanha; a "escola universitária" nos EUA; as "casas das crianças" orientadas por Montessori, na Itália; a "casa dos pequenos", criada por Claparède e Bovet em Genebra; a "escola para a vida", criada por Decroly em Bruxelas, e muitas outras mais (Luzuriaga, 1990; Larroyo, 1974). Apesar das particularidades de cada uma destas experiências, podemos generalizar a importância que davam à articulação da educação intelectual com a atividade criadora, em suas mais variadas expressões, à vida social-comunitária da escola, à autonomia dos alunos $e$ professores; à formação global da criança.

Observa-se nesse importante movimento um aprofundamento da noção de educação integral, diferencial relevante quando comparado à visão iluminista, centrada na instrução, que impregnou a educação durante boa parte do século XIX: nas pedagogias ativas, a educação assenta-se sobre a experiência, individual e grupal, de relações colaborativas e mesmo democráticas, de atividades ligadas à vida cotidiana, da elaboração e consecução de projetos, da ligação entre interesses, aprendizagem $e$ vida. Mesmo retirando a ênfase do aprendizado das artes liberais e dos conhecimentos sistematizados, a Escola Nova pretende proporcionar e estimular a formação integral do estudante.

É claro que a história do ideal de educação integral não se reduz às poucas manifestações aqui indicadas. Acreditamos que essas sejam as mais importantes e que possam trazer luzes para o debate que se desenvolve, nos meios educacionais brasileiros, a respeito da educação integral.

\section{2 - O tema da educação integral na educação brasileira contemporânea}

Desde inícios do século $\mathrm{XX}$, a educação integral é um ideal presente na educação brasileira, seja na legislação, nos projetos $e$ discursos educacionais e na estruturação dos sistemas escolares. 
Com efeito, desde o declínio da influência positivista e o advento da Escola Nova, do Manifesto de 1932 e da obra de Anísio Teixeira, longamente influentes no Brasil, a educação integral está presente nos objetivos das reformas e políticas educacionais. Menos influentes, mas não sem expressão no Brasil, as iniciativas de educação socialista ou libertária também pugnaram pela educação integral. A educação católica, especialmente reforçada com a vinda de ordens religiosas estrangeiras no início do século XX, preserva esse ideal em seus colégios e escolas superiores.

Não parece exagero afirmar que o ideal da educação integral constitui aparente consenso no Brasil, reforçado, nas últimas décadas, pelo mito da escola redentora, que põe na educação as esperanças de desenvolvimento nacional, superação da pobreza, do desemprego, da violência e da criminalidade (BORGES, 2007, p. 01). Um dos indicadores da força desse aparente consenso é a presença do ideal de educação integral na legislação educacional brasileira atual.

Com efeito, o tema aparece no artigo 205 da Constituição Federal (BRASIL, 2018a), sob a denominação de "pleno desenvolvimento da pessoa", ao lado dos dois outros objetivos maiores: "Art. 205. A educação, direito de todos e dever do Estado e da família, será promovida e incentivada com a colaboração da sociedade, visando ao pleno desenvolvimento da pessoa, seu preparo para o exercício da cidadania e sua qualificação para o trabalho".

No Estatuto da Criança e do Adolescente, Lei n ${ }^{\circ}$ 8.069, de 13 de julho de 1990, (BRASIL, 2018b), o tema do desenvolvimento integral da criança e do adoles- cente aparece em numerosos artigos. Na Lei de Diretrizes e Bases da Educação Nacional, Lei no 9394/96 (BRASIL, 2018c), o tema aparece diversas vezes. Em primeiro lugar, já no artigo $2^{\circ}$, como finalidade geral da educação, sob a expressão "pleno desenvolvimento do educando", reverberando o texto constitucional: "Art. $2^{\circ}$ A educação, dever da família e do Estado, inspirada nos princípios de liberdade e nos ideais de solidariedade humana, tem por finalidade o pleno desenvolvimento do educando, seu preparo para o exercício da cidadania e sua qualificação para o trabalho" (BRASIL, 2018c).

Ao tratar da educação infantil, a LDB invoca novamente o tema da educação integral, já sob a expressão "desenvolvimento integral da criança", abrangendo as dimensões física, psicológica, intelectual e social. "Art. 29. A educação infantil, primeira etapa da educação básica, tem como finalidade o desenvolvimento integral da criança de até 5 (cinco) anos, em seus aspectos físico, psicológico, intelectual e social, complementando a ação da família e da comunidade". (Redação dada pela Lei $\mathrm{n}^{\circ} 12.796$, de 2013) (BRASIL, 2018c).

Ao tratar do ensino médio, retoma a LDB o tema, utilizando a expressão "formação integral do aluno", abrangendo esta o projeto de vida e as dimensões física, cognitiva e socioemocional. "Art. 35, §7o - Os currículos do ensino médio deverão considerar a formação integral do aluno, de maneira a adotar um trabalho voltado para a construção de seu projeto de vida e para sua formação nos aspectos físicos, cognitivos $e$ socioemocionais". (Incluído pela Lei $\mathrm{n}^{\mathrm{O}}$ 13.415, de 2017). (BRASIL, 2018c). 
Não há menção explícita à formação integral no capítulo da LDB que trata da educação superior. Longe de ser abandonado, o tema volta à referência nas Diretrizes Curriculares Nacionais de diversos cursos superiores de graduação e nos instrumentos de avaliação de cursos de graduação, sob a vaga expressão: "[...] formação geral do discente, constante do PPC." (BRASIL, 2018e, p. 14).

Cabe mencionar, entre os textos legais de maior interesse para o tema, o Decreto $\mathrm{n}^{\circ} 7.083$, de 27 de janeiro de 2010 (BRASIL, 2018d), que dispõe sobre o Programa Mais Educação. Esse programa inspira-se na educação integral e adota como principal estratégia a ampliação da jornada escolar em escolas públicas de educação básica. Nesse decreto, a educação integral não recebe uma definição, mas é caracterizada, no âmbito do programa, por um conjunto de princípios (artigo $2^{\circ}$ ), entre os quais destacam-se:

I - a articulação das disciplinas curriculares com diferentes campos de conhecimento e práticas socioculturais [...]; II - a constituição de territórios educativos para o desenvolvimento de atividades de educação integral, por meio da integração dos espaços escolares com equipamentos públicos como centros comunitários, bibliotecas públicas, praças, parques, museus e cinemas; III - a integração entre as políticas educacionais e sociais, em interlocução com as comunidades escolares; [...] VI - a afirmação da cultura dos direitos humanos, estruturada na diversidade, na promoção da equidade étnico-racial, religiosa, cultural, territorial, geracional, de gênero, de orientação sexual, de opção política e de nacionalidade, por meio da inserção da temática dos direitos humanos na formação de professores, nos currículos e no desenvolvimento de materiais didáticos.

Ainda que a presença da educação integral nos textos maiores da legislação educacional brasileira baste para confirmar a força desse ideal no Brasil, é cabível analisar a literatura científica da área, o que fazemos por meio de alguns dos trabalhos mais citados, para verificar que sentidos têm sido dados ao termo "educação integral".

Um dos estudos mais importantes é o de Coelho (2009). Ao percorrer em linhas gerais as concepções de educação integral correspondentes às ideologias políticas conservadora, liberal e socialista, que considera as mais representativas dos últimos séculos, a autora identifica na paideia grega a referência basilar do que deve ser denominado 'educação integral':

Conforme podemos constatar, há, na concepção grega de formação humana, uma espécie de igualdade entre as reflexões $e$ as ações que constituem essa formação, sejam elas intelectuais, físicas, metafísicas, estéticas ou éticas. Em outras palavras, há um sentido de completude que forma, de modo integral, o Ser do que é humano e que não se descola de uma visão social de mundo. [...] Acreditamos que esse modo de ver $e$ perceber a formação do homem corresponde à natureza do que denominamos de educação integral: uma perspectiva que não hierarquiza experiências, saberes, conhecimentos. Ao contrário, coloca-os como complementares e fundados radicalmente no social (COELHO, 2009, p. 85).

Assinala também que o debate contemporâneo tem situado a educação integral em relação às políticas públicas referentes à 
escola e à proteção à criança, razão pela qual a educação integral tem sido pensada por meio dos binômios "[...] educação/proteção, educação integral/currículo integrado ou educação integral/tempo escolar" (COELHO, 2009, p. 83). Reconhece um propósito comum em todas as concepções de educação integral: "[...] a busca de uma formação a mais completa possível para o ser humano" (COELHO, 2009, p. 90), mas assinala que, por corresponderem a diferentes visões sociais de mundo, as concepções de educação integral não convergem no que poderia considerar uma formação completa. Conclui que a educação integral inclui formação e informação, abrangendo as atividades tradicionalmente consideradas escolares e também atividades de formação complementar, para o que deve haver um tempo ampliado, em espaços educativos dentro ou fora da escola, mas sempre sob sua orientação e supervisão, para que a ação pedagógica não reste fragmentada ou invalidada. (COELHO, 2009, p. 93-94).

Pestana (2014), ao realizar importante revisão bibliográfica, registra que "[...] as políticas públicas de ampliação do tempo escolar vêm ressignificando a educação integral" (PESTANA, 2014, p. 34), ao associar jornada escolar ampliada e políticas sociais voltadas para o campo educativo (PESTANA, 2014, p. 35). Assim, "A educação integral pode ser entendida como uma possibilidade de garantir condições favoráveis de vida e, consequentemente, proteção social ao sujeito" (PESTANA, 2014, p. 35), por meio de um conjunto de políticas públicas sociais, às quais parece indispensável a ampliação da jornada escolar. Essa perspectiva, que se aproxima de Coelho (2009), é parti- lhada por Silva, Matos de Souza e Cunha (2016, p. 138), que entendem pertencer à concepção contemporânea de "Educação Integral de Tempo Integral" elementos como

[...] a ampliação do tempo escolar; a ampliação das funções da escola, a ampliação do espaço escolar; a ampliação das oportunidades educativas; a formação voltada para os diversos aspectos do ser humano; a universalização da educação; a democratização da educação; a responsabilidade o Estado; a integração entre as políticas educacionais e sociais, etc.; a integração entre os diversos campos do conhecimento, dentre outros.

Essa concepção ressignificada de educação integral aparece com mais clareza no estudo de She, Gouveia e Ferreira (apud., PESTANA, 2014, p. 34):

No que tange às novas gerações, entende-se por educação integral aquela que propicia o desenvolvimento integral de crianças e adolescentes $e$ que acontece por meio de situações de aprendizagem que oportunizam, simultaneamente, a ampliação de capacidade para a convivência $e$ participação na vida pública; a ampliação de repertórios de competências e habilidades e o acesso e o usufruto aos serviços sociais básicos. Assentado nessa conjugação de princípios e finalidades, o conceito de educação integral inclui a cidade, seus espaços, recursos $e$ acontecimentos como campo estratégico de aprendizagens e desenvolvimento de crianças, adolescentes e de todos os seus habitantes. Assim, a centralidade passa a ser o território e as experiências nele vividas.

Esse trecho parece bastante elucidativo quanto ao que afirma e quanto ao que omite. Afirma que a educação integral é proporcionada por situações de aprendiza- 
gem voltadas para a convivência e participação na vida pública, para o que é necessário o desenvolvimento de competências e habilidades, bem como o acesso e o usufruto de serviços sociais básicos. Entretanto, ao afirmar que "[...] entende-se por educação integral aquela que propicia o desenvolvimento integral de crianças e adolescentes", fica patente não apenas a tautologia, mas principalmente a falta de um conceito de desenvolvimento integral. A integralidade da pessoa humana, que a educação integral pretende desenvolver, parece ficar reduzida à sua dimensão social.

É o que fica patente na afirmação de Pestana (2014, p. 37): "Esta forma contemporânea de entendimento não 'reduz' a educação integral à ideia histórica de formação humana, mas busca outras relações, direcionadas por essas variadas políticas públicas que têm, como base, a proteção social". Compreenda-se bem o equívoco dessa afirmação: a autora considera a ideia de formação humana integral, desenvolvida desde a paideia grega e helenística até pelo menos a Bildung germânica, como uma redução da educação integral a algumas manifestações históricas; para tomar a educação integral em perspectiva efetivamente ampla é necessário considerá-la como proteção social direcionada por políticas operadas pelo Estado. $\mathrm{Na}$ verdade, ao propor essa forma de relacionamento da educação integral com a necessidade de políticas públicas adequadas, não se está aprofundando ou enriquecendo o conceito de educação integral, nem mesmo o ampliando, mas apenas confundindo sua essência (o desenvolvimento da pessoa humana) com os meios necessários para sua concretização num contexto de sociedade de massas. Em outros termos, está substituindo a educação da pessoa humana em sua integralidade pela totalidade dos meios para educação da pessoa.

Sem que a afirmação a seguir represente qualquer menosprezo aos esforços políticos e econômicos pela ampliação da jornada escolar e da proteção social do estudante, a análise desses textos mostra que a concepção de educação integral que esses autores denominam genericamente de "perspectiva contemporânea" não traz efetiva contribuição à construção de uma educação integral. Ao contrário, pode representar desvio, na medida em que, eivada de um materialismo histórico difuso e pouco sistemático, a perspectiva contemporânea parece desejar descartar a tradição filosófica e pedagógica multimilenar em favor de uma concepção que reduz o ser humano à sua dimensão social. Desprezam-se contribuições relevantes na tradição filosófica e pedagógica, em nome de uma concepção mais estreita. Em nome do propósito de ampliar a integralidade, pode-se simplesmente perder $\mathrm{o}$ humano que se deseja formar.

Assim procedendo, ficam sem resposta algumas questões relevantes, como por exemplo: (i) Quais são as dimensões do ser humano que devem ser objeto de ações educativas na infância, na adolescência, na juventude e na idade adulta? (ii) Sobre quais dessas dimensões seria lícito a escola influir, direcionar, orientar e avaliar? (iii) Quais são os direitos, deveres e responsabilidades da sociedade e do Estado, sobre as dimensões a serem desenvolvidas a partir de processos educativos? (iv) Quais são os direitos, deveres $e$ as responsabilidades que cabem às famílias e aos próprios indivíduos? (v) Que 
conteúdos e respectivos fundamentos deveriam ser ensinados no tocante a comportamentos morais, princípios éticos, estética, relações humanas, vida sentimental, projeto de vida, hábitos de consumo, projeto de carreira, e tantos outros que pertencem mais à esfera subjetiva que à social? (vi) Quem teria direitos sobre a definição desses conteúdos?

Há muito o que refletir a respeito da educação integral. Somente uma filosofia do ser humano capaz de apreendê-lo em suas múltiplas dimensões, muito além da social, fornecerá bases para a construção de uma educação integral adequada às necessidades da cultura contemporânea.

\section{3 - O ideal de educação integral $e$ as teorias educacionais}

Se se considerar que a educação integral é, desde os gregos, um ideal recorrente no pensamento educacional, é cabível perguntar como ele se situa em relação às teorias educacionais. Estas têm sido, desde algumas décadas, objeto de intensa reflexão $e$ meticulosa classificação, na literatura especializada brasileira e europeia.

As tentativas de classificação resultam, em primeiro lugar, da ampla variedade e quantidade de teorias educacionais, elaboradas segundo diferentes objetivos, diferentes fundamentações teóricas e diferentes escopos. De seu exame resultam concordâncias, discrepâncias e até mesmo contradições. Daí a necessidade de mapeá-las e compará-las. Em segundo lugar, o objetivo de tais classificações é frequentemente político. Uma classificação de teorias educacionais visa a identificar adversários e possíveis aliados no debate e na ação política, em que estão em jogo não apenas ideias e direcio- namentos institucionais, mas recursos, postos de direção e poder político. Mais nítido em algumas classificações que em outras, o caráter político é constitutivo desse trabalho, pois, conforme sentencia Gadotti (1990, p. 23), "Todo pensamento pedagógico é tributário de sua época e é ingênuo lê-lo desvinculado de um movimento histórico-social $e$ de um projeto político e social".

O resultado dessa classificação é, naturalmente, múltiplo e divergente, refletindo os diferentes pressupostos epistemológicos, metodológicos, antropológicos, pedagógicos e sociopolíticos. Murakami (2001), por exemplo, divide as teorias educacionais em abordagem tradicional, abordagem comportamentalista, abordagem humanista, abordagem cognitivista e abordagem sociocultural, com a qual se identifica. Gadotti (1990), em elaborada recensão crítica do pensamento educacional dos anos 1980, prefere classificar por correntes, que descreve como pedagogia do oprimido, educação popular, educação como descoberta do prazer de ensinar e aprender, educação como paixão de descobrir o mundo, crítica da escola capitalista, pedagogia dos conteúdos, e, por fim, pedagogia do conflito, com a qual o autor se identifica.

Já Libâneo (2010), de forma muito lúcida e abrangente, traz o debate para o ambiente cultural da pós-modernidade $e$ abrange contribuições brasileiras, europeias e norte-americanas. Divide as teorias pedagógicas em modernas (abrangendo da Reforma a Dewey) e contemporâneas, compreendendo por sua vez correntes que contêm modalidades. A corrente racional-tecnológica divide-se nas modalidades ensino de excelência e ensino tecnológico; a corrente neo- 
cognitivista aglutina o construtivismo póspiagetiano e as ciências cognitivas; a corrente sociocrítica compreende a sociologia crítica do currículo, a teoria histórico-cultural, a teoria sociocultural, a teoria sociocognitiva e a teoria da ação comunicativa; a corrente holística compreende o holismo, a teoria da complexidade, a teoria naturalista do conhecimento, a ecopedagogia e o conhecimento em rede; a corrente pós-moderna abrange o pós-estruturalismo e o neopragmatismo.

Saviani (2007), retomando diversas obras anteriores, divide as teorias educacionais por sua relação com a concepção tradicional de educação, concepção humanista moderna, concepção analítica, concepção crítico-reprodutivista e concepção pedagógica dialética, ou histórico-crítica, com a qual o autor se identifica. Oportunamente, distingue nelas três níveis de articulação conceitual $e$ prática: o nível da filosofia da educação, o nível da teoria da educação, ou pedagogia $e$ o nível da prática pedagógica. Tais níveis se articulam diferentemente em cada uma das concepções educacionais apontadas.

Como se situa o tema da educação integral com referência às teorias educacionais? Tomando por base a classificação de Saviani (2007), que é uma das mais conhecidas e adotadas, procuraremos esboçar as relações entre elas e a educação integral.

A concepção tradicional de educação, de acordo com Saviani (2007), toma por base uma visão essencialista do ser humano, reduzindo a teoria educacional aos enunciados filosóficos dela derivados e a prática pedagógica à "[...] tarefa de conformar cada indivíduo à essência ideal e universal que caracteriza o homem" (SAVIANI, 2007, p. 17). Entretanto, equivoca-se Saviani (2007) ao supor que indivíduos concretos terão de ser conformados a uma essência, como numa cama de Procusto. Com efeito, a essência de um ente não lhe é externa, mas ínsita, inerente e estruturante. A pessoa humana, qualquer que seja seu estágio de desenvolvimento, é um ente que já possui tal essência. Cabe à educação a tarefa de estimular e apoiar o pleno desenvolvimento e atualização das potencialidades contidas na essência humana. Nessa perspectiva, Jacques Maritain (1966, p. 63), filósofo neotomista francês, caracteriza a educação como "ars cooperativa naturae", isto é, arte de cooperar com a natureza do ser humano, tomada amplamente, muito além de sua dimensão biológica. Não cabe à educação, portanto, tolher o ser humano, mas apoiar seu desenvolvimento. Nesse sentido, a educação a ser buscada é necessariamente integral, isto é, aquela que provê recursos pedagógicos para promover o desenvolvimento completo do ser humano, capacitando-o para melhor viver em circunstâncias existenciais concretas, interagir com elas e até mesmo transformálas. Quanto à deformação conceitual provocada pela classificação de Saviani (aliás, abusivamente generalizadora), resta refletir se consiste em improvável equívoco conceitual ou mero ataque político.

A concepção humanista moderna, voltada para os indivíduos considerados em suas diferenças, relações mútuas e situações existenciais, busca apoio nas ciências (especialmente na biologia, psicologia e sociologia) para constituir as pedagogias escolanovistas, caracterizadas por valorizar a atividade, as experiências e o interesse dos educandos (cf. SAVIANI, 2007, p. 17). A educação integral não é ideia estranha a essa cor- 
rente pedagógica, conforme anteriormente observado (CAVALIERE, 2002). Pelo contrário, a recusa de uma educação tãosomente intelectualista e a busca de uma educação que atenda às necessidades da vida do educando coincide com a busca de uma educação que desenvolva a plenitude do ser humano. É o que indica Francine Dubreucq (2010, p. 58), diretora do Centro de Estudos Decrolianos de Bruxelas, Bélgica:

Ainda que existam muitas diferenças entre esses $e$ outros autores enquadrados nessa corrente, aspecto comum está no deslocamento que promoveram no foco pedagógico: do verbalismo da educação tradicional centrada no professor ao ativismo focado no mundo do aluno. Ideias e conceitos como educação ativa, psicologia genética, experimentalismo, autoformação, aprendizagem contínua, educação integral, centro de interesses, jogos educativos, educação funcional, trabalho em equipe, entre outros, compunham o mosaico da "Escola Nova" (ou "escolas novas").

Observe-se, por fim, que a concepção de ser humano que informa as teorias pedagógicas da Escola Nova é fortemente influenciada pelas teorias científicas em que se fundamentam, o que pode representar certa limitação no alcance filosófico das teses sobre o sujeito humano. Entretanto, o enorme desenvolvimento científico e técnico das pedagogias ligadas à Escola Nova representa contribuição significativa para todas as iniciativas que pretendam promover uma educação integral do ser humano.

Saviani (2007, p. 17) apresenta a concepção analítica de educação como uma pedagogia tecnicista, lastreada nos princípios da racionalidade, eficiência e produtividade, bem como fundada no conhecimento positivo e pretensamente neutro. Seus pressupostos epistemológicos se aproximam do positivismo e da psicologia behaviorista. Não há preocupação manifesta com o ideal de educação integral. Pelo contrário, a ênfase dada aos princípios da racionalidade e do conhecimento positivo leva à desvalorização da arte, da estética, dos sentimentos e de qualquer tipo de espiritualidade. Por outro lado, a ênfase nos princípios da eficiência e da produtividade desvaloriza as ações educativas que não visam concretizá-los e distancia as iniciativas educacionais dessa corrente da busca de alguma forma de educação integral.

A concepção crítico-reprodutivista da educação exprime-se como teoria científica que pretende "[...] explicar os mecanismos sociais que compelem a educação a exercer necessariamente a função de reprodução das relações sociais dominantes, independentemente do tipo de prática pedagógica que venha a ser implantada" (SAVIANI, 2007, p. 18). Ignorando o tema da prática pedagógica e analisando o fenômeno da reprodução, essa corrente não pretende promover a educação integral, mas curiosamente, parece admitir sua existência, ao pretender examinar a reprodução como fenômeno totalizante.

A concepção histórico-crítica, também denominada "dialética" ou "pedagogia dos conteúdos", tem em Dermeval Saviani (2007) seu principal representante no Brasil. Pretende articular dialeticamente a filosofia da educação, a teoria educacional e a prática pedagógica, fazendo desta última o ponto de partida e o ponto de chegada da práxis pedagógica, cujas mediações são a teoria da 
educacional e a filosofia da educação (SAVIANI, 2007, p. 18).

Trata-se de uma pedagogia inspirada no pensamento de Marx (1968) e de Gramsci (1991), que pretende ser revolucionária $e$ contra-hegemônica, voltada para a superação das desigualdades sociais e da visão liberal-burguesa de educação. A estratégia dessa pedagogia consiste em "[...] transmitir aos trabalhadores os conhecimentos clássicos, eruditos, para que eles tenham condições de elevar-se culturalmente e assim, lutar pela libertação da exploração e dominação da classe dominante" (BACZINSKI, et al., 2018, p.1). O papel da escola é, portanto socializar o conhecimento sistematizado, permitindo aos estudantes compreender $e$ participar da sociedade de forma crítica, transitando do nível do senso comum ao nível da consciência filosófica.

Nesse sentido, Saviani (2007) concebe a educação como "[...] o ato de produzir, direta $e$ intencionalmente, em cada indivíduo singular a humanidade que é produzida pelo conjunto dos homens" (SAVIANI, 2000, p.17). Entretanto, sua concepção de ser humano não é essencialista: "Podemos, pois, dizer que a natureza humana não é dada ao homem, mas é por ele produzida sobre a base da natureza bio-física" (SAVIANI, 2000, p. 17). Numa fórmula sintetizadora, afirma:

Em conclusão: a compreensão da natureza da educação enquanto um trabalho não-material cujo produto não se separa do ato de produção nos permite situar a especificidade da educação como referida aos conhecimentos, ideias, conceitos, valores, atitudes, hábitos, símbolos sob o aspecto de elementos necessários à formação da humanidade em cada indivíduo singular, na forma de uma segunda natureza, que se produz, deliberada $e$ intencionalmente, através de relações pedagógicas historicamente determinadas que se travam entre os homens (SAVIANI, 2000, p. 28).

Como se situa, na perspectiva desse autor, o tema da educação integral? Também aqui não há menção explícita. Mas os trechos transcritos permitem afirmar que Saviani (2007), ao conceituar a educação como produção da humanidade em cada indivíduo, isto é, de uma segunda natureza que torna o indivíduo humano, o autor está sem dúvida referindo-se a uma educação integral, não relacionada à essência humana, mas à concepção de ser humano que é criada histórica e socialmente em cada época. Em outros termos, ao determinar um objetivo bastante amplo para a educação, Saviani (2007) propõe uma forma de educação integral. A uma conclusão semelhante chegam Pattaro e Machado (2014, p. 124) ao analisar as aproximações possíveis entre a pedagogia histórico-crítica de Saviani e a educação integral:

Por 'compreender a educação como setor fundamental para todo o desenvolvimento que preconize o homem como sujeito central' [...], a teoria histórico-crítica prevê a ele um desenvolvimento social global, 'dependente da educação, ao mesmo tempo em que a educação é entendida como condicionada à realidade, principalmente por sua estrutura política' (SAVIANI, 2008, p. 92). Para isso, é preciso considerar o homem na inteireza de suas dimensões física, biológica, psicológica e cultural, sendo, por essa configuração, o agente dentro do processo de transformação do meio no qual vive, ao mesmo tempo em que é transforma- 
do por ele. Esse caráter de mediação $e$ de integralidade tanto do ser humano, quanto de sua realidade composta pelas relações sociais $e$ suas contradições, comportam os ideais da educação integral.

Finalmente, é oportuno mencionar um importante trabalho de Saviani (2003), em que o autor, analisando as consequências da terceira revolução industrial, assinala a necessidade de uma educação escolar voltada para o pleno desenvolvimento humano, ainda que combatida e retardada pelas relações sociais vigentes:

Assim, se naquele período esse processo converteu a escola na forma principal e dominante de educação, atualmente parece que estamos atingindo o limiar desse mesmo processo quando o próprio desenvolvimento da base produtiva coloca a necessidade de universalização de uma escola unitária que desenvolva ao máximo as potencialidades dos indivíduos (formação omnilateral), conduzindo-os ao desabrochar pleno de suas faculdades intelectuaisespirituais (SAVIANI, 2003, p.148).

Saviani (2003; 2007), como tantos outros autores ao longo da história do pensamento pedagógico, partilha do ideal de educação integral, apesar de conferir-lhe outro nome. Poderíamos supor consenso entre tais autores, dado que buscam uma educação do ser humano como um todo? Certamente não. As divergências, quase sempre profundas e às vezes inconciliáveis, residem principalmente na concepção do que é o ser humano em sua integralidade. Metafísicos e materialistas, históricoexistencialistas $e$ essencialistas, filósofos $e$ cientistas, pensam e atuam com base em concepções distintas de ser humano. Pensar a educação, em especial a educação integral, requer, primeiramente, responder à pergunta: "o que é o ser humano?".

\section{Considerações finais}

Este ensaio buscou - na história do pensamento pedagógico, na legislação educacional brasileira e na literatura cientifica da área - reunir elementos que permitissem compreender em que consiste a educação integral e como esse ideal foi conceitualmente apreendido. Acreditamos, com isso, contribuir com professores e pesquisadores para o aprofundamento da pesquisa e das discussões referentes à educação integral. É notável, contudo, que o ideal de educação integral, acalentado por pensadores, legisladores, formuladores de políticas públicas e especialistas da área, se mostre em formas conceituais pouco aprofundadas $e$ acentuadamente divergentes.

Algumas conclusões, mesmo que preliminares, foram alcançadas. A primeira é, na verdade, uma constatação. Ao longo da cronologia histórica desenvolvida, a noção de educação integral sofreu tantas e tão profundas mudanças que devem ser consideradas ingênuas as abordagens que a tomam como um conceito homogêneo ou como continuidade da paideia grega. Quaisquer referências à educação integral requerem, portanto, maior precisão conceitual e histórica.

A segunda conclusão é que o consenso em torno da necessidade da educação integral, no Brasil, é de fato apenas aparente, pois os estudos constantes na literatura científica da área pouco avançam além das definições mais genéricas, deixando intocados aspectos relevantes à temática. Nos últi- 
mos anos, esses estudos têm avançado em direção às políticas públicas, a ponto de operar a redução da educação integral a uma associação de políticas de proteção social, em que categorias como "território" ganham centralidade.

A última conclusão é de que o debate contemporâneo sobre a educação integral ainda carece de uma filosofia do ser humano que discuta a integralidade de suas dimen- sões constitutivas e permita sua expressão em termos de necessidades educativas. Sem essa discussão, a proposição de objetivos para a educação integral carecerá de referenciais norteadores e tenderá a reduzir-se, como já vem ocorrendo, aos aspectos sociais ou curriculares.

\section{Referências}

AGOSTINHO, Santo. Confissões; De Magistro (Do Mestre).2.ed. São Paulo: Abril Cultural, 1980. (Os Pensadores).

ARISTÓTELES. Política. eBooket. Disponível em: $<$ http://www.dominiopublico.gov.br/pesquisa/PesquisaObraForm.do?select_action=\&co_auto $\mathrm{r}=144>$. Acesso em: 20 nov. 2018.

AMADO, Casimiro Manuel Martins. História da pedagogia e da educação: guião para acompanhamento das aulas. Évora, Universidade de Évora, 2007. Disponível em: <http://home.dpe.uevora.pt/ casimiro/HPE-\%20Guiao\%20-\%20tudo.pdf>. Acesso em: 20 nov. 2018.

BACZINSKI, Alexandra Vanessa de Moura et al. A implantação da pedagogia histórico-crítica no Paraná: considerações a partir de uma atividade de extensão. Disponível em: < http://www.histedbr.fe.unicamp.br/acer_histedbr/jornada/jornada11/artigos/5/artigo_simposi o_5_600_alexandra.vanessa@hotmail.com.pdf >. Acesso em: 16 dez. 2018.

BAPTISTA, Marlon. Considerações sobre o romance de formação. Educação Pública. CECIERJ, $2009 . \quad$ Disponível em: $<$ http://www.educacaopublica.rj.gov.br/biblioteca/filosofia/0043.html >. Acesso em: 20 nov. 2018.

BRASIL. Constituição da República Federativa do Brasil de 1988. Disponível em: $<$ http://www.planalto.gov.br/ccivil_03/Constituicao/Constituicao.htm> . Acesso em: 20 nov. 2018a.

BRASIL, Lei n 8.069, de 13 de julho de 1990. Dispõe sobre o Estatuto da Criança e do Adolescente dé outras providências. Disponível em: <http://www.planalto.gov.br/ccivil_03/LEIS/L8069.htm>. Acesso em: 20 nov. 2018b.

BRASIL. Lei n. 9.394/96, de 20 de dezembro de 1996. Estabelece as diretrizes e bases da educação nacional. Disponível em: <http://www.planalto.gov.br/ccivil_03/LEIS/L9394.htm>. Acesso em: 20 nov. 2018c. 
BRASIL. Ministério da Educação. Instituto Nacional de Estudos e Pesquisas Educacionais Anisio Teixeira. Diretoria de avaliação da Educação Superior. Instrumento de avaliação de cursos de graduação: presencial e a distância: reconhecimento, renovação de reconhecimento. Brasília, out. $2017 . \quad$ Disponível em:< http://download.inep.gov.br/educacao_superior/avaliacao_cursos_graduacao/instrumentos/201 7/curso_reconhecimento.pdf' > . Acesso em: 20 nov. 2018 d.

BRASIL, Decreto $n^{\circ}$ 8.073, de 27 de janeiro de 2010. Dispõe sobre o Programa Mais Educação. Disponível em: <http:/www.planalto.gov.br/ccivil_03/_Ato20072010/2010/Decreto/D7083.htm. > . Acesso em: 20 nov. 2018e.

COELHO, Lígia Martha C. da Costa. História(s) da educação integral. Em aberto, Brasília, v.22, n. 80, abr. 2009, p. 83-96.

COMENIUS, Iohannis Amos. Didactica magna. Lisboa: Calouste Gulbenkian, 2001. Versão digital de eBooksBrasil.com .

COMTE, Auguste. Comte: Os Pensadores. São Paulo: Abril, 1978. (Os pensadores).

DALBOSCO, Cláudio Almir (org.) Filosofia e Educação no Emílio de Rousseau: o papel do educador como governante. Campinas: Alínea, 2011.

DUBREUCQ, Francice. Jean-Ovide Decroly. Recife: Fundação Joaquim Nabuco-Editora Massangana, 2010. (Educadores MEC). Disponível em: <http://www.dominiopublico.gov.br/download/texto/me4668.pdf>. Acesso em: 16 dez. 2018.

FRANCA, Leonel. O método pedagógico dos jesuítas: o Ratio Studiorum - introdução e tradução. Rio de Janeiro: AGIR, 1952. (Obras completas do Pe. Leonel Franca SJ).

GADOTTI, Moacir. Pensamento pedagógico brasileiro. 3.ed. São Paulo: Ática, 1990.

GONÇALVES, Antônio Sérgio. Reflexões sobre educação integral e escola de tempo integral. Cadernos CENPEC, v. 1, n. 2, 2006. p. 129-135.

GRAMSCI, Antonio. Os intelectuais e a organização da cultura. 3.ed. Rio de Janeiro: Civilização Brasileira, 1991.

HABERBERGER, Clara. A return to understanding: making liberal education valuable again, Educational Philosophy and Theory, v.50, n.11, p. 1052-1059, 2018. Disponível em: $<$ https:/www.tandfonline.com/doi/pdf/10.1080/00131857.2017.1342157?needAccess=true $>$ - Acesso em: 22 jan. 2019.

HISTORY of a liberal arts education. Liberal Arts College Review, New York, march 31, 2017. Disponível em: <http:/www.liberalartscollegereview.com/articles/11>. Acesso em: 22 jan. 2019.

LARROYO, Francisco. História geral da pedagogia. 4.ed. São Paulo: Mestre Jou, 1982. Tomo I.

MACIEL, Antonio Carlos; JACOMELLI, Mara Regina Martins; BRASILEIRO, Tânia Suely Azevedo. Fundamentos da educação integral politécnica: da teoria à prática. Educação e Sociedade, Campinas, v. 38, n. 139, p. 473-488, abr.-jun. 2017.

MARITAIN, Jacques. Rumos da educação. 4.ed., Rio de Janeiro: Agir, 1966. 
MARROU, Henri-Irénée. História da educação na antiguidade. 4.reimp. São Paulo: EPU; Brasília: INL, 1975.

MARX, Karl. O Capital. Rio de Janeiro: Civilização Brasileira, 1968. v.1.

MIZUKAMI, Maria da Graça Nicoletti. Ensino: as abordagens do processo. São Paulo: EPU, 1986. (Temas básicos de educação e ensino).

MORENTE, Manuel Garcial. Filosofia: lições preliminares. São Paulo, Mestre Jou, 1967.

PATTARO, Rita de Cássia Ventura; MACHADO, Vera Lúcia de Carvalho. Educação integral e a perspectiva histórico-crítica: aproximações possíveis. Educação, Santa Maria, v. 39, n. 1, p. 117-128, jan.-abr. 2014.

PESTANA, Simone Freire Paes. Afinal, o que é educação integral? Revista Contemporânea de Educação, v. 9, n. 17, jan./jun. 2014, p. 24-40.

PETERSON, Patti McGill. A educação liberal na perspectiva global. Revista Ensino Superior Unicamp, Campinas, Universidade Estadual de Campinas, n. 3, p. 42-44, jun.set. 2011. Disponível em: <https://www.revistaensinosuperior.gr.unicamp.br/artigos/o-que-e-educacaoliberalij>. Acesso em: 05 mar. 2018.

PLATÃO. Diálogos: O Banquete - Fédon - Sofista - Político. 2.ed. São Paulo: Abril Cultural, 1983. (Os pensadores).

PLATÃO. A República. Trad. Carlos Alberto Nunes. 3.ed. Belém: EDUFPA, 2000.

PLATO. Laws. Trad.Benjamin Jowett. The Project Gutenberg Ebook, 2003. Disponível em: $<$ http://www.dominiopublico.gov.br/download/texto/gu001750.pdf $>$. Acesso em: 20 nov. 2018.

REALE, Giovanni; ANTISERI, Dario. História da filosofia: antiguidade e idade média - volume I. 3.ed. São Paulo: Paulus, 1990a. (Filosofia).

REALE, Giovanni; ANTISERI, Dario. História da filosofia: do Humanismo a Kant - volume 2. São Paulo: Paulisnas, 1990b.

ROUSSEAU. Emílio ou da educação. 3.ed., Rio de Janeiro: Bertrand Brasil, 1995.

SAVIANI, Dermeval. Epistemologia e teorias da educação no Brasil. Pro-posições, v. 18, n. 1(52), jan.-abr. $2007 . \quad$ Disponível em: <https://periodicos.sbu.unicamp.br/ojs/index.php/proposic/article/view/8643570/11091>. Acesso em: 16 dez. 2018.

SAVIANI, Dermeval. Pedagogia histórico-crítica: primeiras aproximações. 7. ed., Campinas: Autores Associados, 2000. (Polêmicas do Nosso Tempo, 40).

SILVA, Luciene; MATOS DE SOUZA, Maria de Fátima Matos; CUNHA, Célio. A influência do pensamento pedagógico brasileiro na política de educação integral do século XXI. Revista HISTEDBR On-line, Campinas, n. 69, p. 124-139, set. 2016.

SIMARD, Denis. L'éducation peut-elle être encore une "éducation libérale"?. Revue française de pédagogie, Institut National de Recherche Pedagogique, v. 132, p. 33-41, juillet-aoûtseptembre 2000. Evaluation, suivi pédagogique et portfolio. Disponível em: 
<http://www.persee.fr/doc/rfp_0556-7807_2000_num_132_1_1031>. Acesso em: 05 mar.2018.

SUAREZ, Rosana. Notas sobre o conceito de Bildung (formação cultural). Kriterion, Belo Horizonte, n. 112, dez. 2005, p. 191-198.

STRAUSS, Leo. O que é educação liberal? Revista Ensino Superior Unicamp, Campinas, Universidade Estadual de Campinas, n. 3, jun.set. 2011. Disponível em: https://www.revistaensinosuperior.gr.unicamp.br/artigos/o-que-e-educacao-liberalij. Acesso em: 05 mar. 2018. 